\title{
Resource Complementarity and Performance in Technology-Intensive Mergers and Acquisitions"
}

\author{
WON-SEOK WOO**
}

This paper examines the influence of complementarity between technological resources and functional resources in expost performance of mergers and acquisitions. While prior work has looked at complementarity as an indication of fit within a particular resource domain, this study focused on the complementarity between different resource domains. We specifically tested the performance impact associated with complementarity between the technological resources of the one merger partner and the functional resources of the other merger partner, including financial, marketing and operational resources. Performance was measured in both marketbased (i.e., ex ante stock market returns at announcement) and operational terms (i.e., ex post increases in sales revenues of the combined firm). Our results indicate that complementarities between a target's technological resources and the acquirer's financial and marketing resources produce positive effects on post-merger sales growth and ex-ante stock market returns. Surprisingly, our results also revealed that complementarity between the target's technological resources and the acquirer's operational resources had a negative effect on post merger sales growth. We discuss the implications of these findings for managers contemplating mergers and acquisitions.

Keywords: Resource Complementarity, M\&A Performance, Technology-Intensive Industries

"This research was supported by the Ewha University's "New Faculty Research Fund (\# 2004-0904-1)."

** Assistant Professor, Graduate School of International Studies; Ewha Womans University, 11-1 Daehyun-Dong, Seodaemun-Gu, Seoul, 120-750, Korea; Tel: 82-2-3277-4455; E-mail: wwoo@ewha.ac.kr 


\section{INTRODUCTION}

I ndustries and markets characterized by rapid changes, so-called "high velocity environments" (Eisenhardt and Bourgeois 1988) present special challenges to managers as they seek to improve firm performance. Because these environments experience volatile changes in demand along with discontinuous technological change (Eisenhardt 1989), it is difficult for managers to gain and sustain competitive advantage. In this context, mergers and acquisitions (M\&A) have been seen as a key mechanism to help firms adjust their resource configuration to such rapidly changing circumstances. It has been duly noted that $M \& A$, rather than internal development, can help firms avoid some of the risks associated with innovation and the time constraints imposed by continuous change (Barney 1991; Peteraf 1993). Consequently, the conditions under which M\&As help firms improve performance has become a critical issue for investigation.

Early research on the impact of M\&As on firm performance looked at the concept of "relatedness" between acquirer and target from a product-market perspective (Markides and Williamson 1994). Later work, however pointed to the presence of inimitable and uniquely valuable synergy between acquirer and target firms (Barney, 1988) and the opportunity to share resources and activities between merger participants (Brush 1996) as crucial contributors to M\&A performance. This work argued that the creation of synergies is a key factor in securing the potential benefits accruing to the firms involved in M\&As. This capacity for combining two firms in such a way that the subsequent whole is greater than the sum of its parts is thought to emerge from operational, financial or collusive means (Bradley 1988). For acquisition strategies to produce economic value, the resultant entity must create a distinctive competence (Marcus and Geffen 1998) based on what the individual firms bring to the combined entity. This typically takes the form of the transfer of resources and/or competencies to and from an acquisition target, which has been argued is a key driver of improved performance post acquisition (cf, Dussauge and Mitchell 1998; Chatterjee 1986). To date, research that has tried to trace post M\&A performance to the resource endowments of the participating firms has focused on the degree to which resources within a specific functional area are complementary. For example, Chatterjee (1986) found that the degree to which acquiring firms brought abundant financial resources to a target that lacked access to such resources resulted in better post-merger performance. Similarly, Larsson and Finkelstein (1999) examined the ex ante performance of M\&As between, say, an acquiring firm with stronger marketing resources and a target with weak marketing resources.

The focus of this paper is on the degree of complementarity of different classes of resources between the acquiring firm and the target in rapidly changing economic environments. For example, with markets undergoing rapid technological change, the survival of firms typically depends on the ability to develop new marketable 
products on their own or obtain technology (or other assets) through acquisitions (Blonigen and Taylor 2000). Such complementarities have been seen as valuable because the interaction of combined resources increases firm effectiveness and efficiency (Walker and Ruekert 1987). Moreover, firms exhibiting complementarities are likely to inhibit potential entrants that find them difficult to imitate (Lippman and Rumelt 1982). Consequently, the degree to which a target firm brings innovative technological resources to the post-M\&A firm, coupled with the acquiring firm's access to superior financial resources, may result in the necessary post-acquisition synergy capable of improving performance above pre-acquisition levels. We examined the effect of complementary resources in financial, marketing, operational and technological areas between acquirer and target, using M\&As done worldwide in high technology industries during the 1984 to 1996 period. We specifically looked at both short term performance, using short term ex ante stock market returns upon announcement of the M\&A and longer-term performance using ex post sales growth.

This study has implications for the way in which synergies can arise following M\&A activity. Recent work has begun to question whether synergies of the sort promised by CEOs following a merger are readily attainable (Hayward and Hambrick 1997; Sirower 1997). Our results indicate that the types of situations from which synergies might arise go beyond those previously examined. Consequently, they offer managers of acquiring firms valuable insights for analyzing potential acquisition targets. At the same time, our results also point to situations where synergies are less likely to emerge, given the resource combinations of the participating firms. While others have blamed hubris for contributing to the failure of M\&As to deliver value to shareholders of acquiring firms (at least at the promised levels; Hayward and Hambrick 1997), our results indicate that difficulties may stem from the nature of the firms themselves, and not just (or perhaps, primarily) the exaggerated sense of self-confidence that can sometimes afflict CEOs. Therefore, this study joins a growing list of others that have argued for the important influence that such cross-resource complementarities have on firm performance in highly dynamic environments (Milgrom and Roberts 1995).

\section{RESEARCH ON PERFORMANCE OF MERGERS AND ACQUISITIONS}

The performance implications of M\&As have been of considerable interest to strategy researchers over the last couple of decades. In the strategy literature, performance of M\&As has often been referred to as value creation or wealth creation (Seth 1990a). There is empirical evidence that acquisitions, on average, create economic value (Anand and Singh 1997). The mainstream of research on the sources of M\&A value creation focuses on whether the degree or level of relatedness between two firms will determine the performance of M\&As (Chatterjee 1986; Shelton 
1988). The relatedness hypothesis has been tested quite extensively in strategy research yielding inconsistent results. For example, Lubatkin (1987) and Singh and Montgomery (1987) found that the difference in returns to acquiring firm shareholders for strategically related and unrelated acquisitions was not significant.

Another stream of M\&A research attempts to explain the performance differences based on process and organization related factors. These factors include organizational fit (Datta 1991) and cultural compatibility (Chatterjee et al. 1992), as well as the acquisition process itself, which is a potentially important determinant of outcome (Trautwein 1990; Jemison and Sitkin 1986).

Most recently, a growing number of studies examine M\&A performance from the standpoint of the resource-based view (RBV). According to these studies, relatedness in an M\&A may not be a sufficient condition for acquiring firms to perform well. Rather, only when acquiring firms enjoy private, inimitable and uniquely valuable synergistic cash flows with target firms, will acquiring a related firm result in better performance for the acquiring firms (Barney 1988). Operating synergy was found to be achieved primarily from the changes in the opportunity to share resources and activities between acquiring and acquired firms (Brush 1996). Strategic fit, not in terms of conventional relatedness in product and market, but in terms of resource or capability complementarities may explain the performance differences in the M\&As. Larsson and Finkelstein (1999) found that the presence of complementary operations increased the probability of acquisition success by boosting synergy realization. This reciprocal complementarity of resources/capabilities may thus be one of the main factors that determine the performance of certain M\&As.

Larsson and Finkelstein (1999) analyzed 61 M\&A cases to test their conceptual framework. For their combination potential construct, they looked at two complementary capabilities - complementarities of marketing operations and complementarities of production operations. Their definition of complementarities of capabilities was based on the relative strength of a certain capability. For example, there was a high combination potential from complementarities when the acquiring firm possessed a strong marketing capability and the target firm was weak in this capability. The performance variable was more subjective and was found from complementarities of capabilities, which was measured through case analysis.

Harrison, Hitt, Hoskisson and Ireland, (1991) tested the hypotheses regarding the differences vs. similarities in resource allocations and their impact on post-acquisition performance. Their finding suggests that differences in resources between acquiring and target firms contributes significantly to performance in the merged entity and that a focus on specific resources may better explain firm performance. In these studies, the classification of similar and different resource allocations was based on the difference between acquiring and target firm's same resource category - for example, the difference in R\&D intensity between two merged firms.

Mitchell (1994), Nelson and Winter (1982), and Teece (1987) argue that acquisitions allow acquiring firms to employ their existing resources for new uses. Firms with 
strong underutilized resources will tend to seek targets with complementary weaknesses. The managers of an acquiring firm may think that they have more than sufficient complementary resources needed for the combination with the acquired firm and consequently offer a higher price than other potential buyers.

A few contributions in the management literature emphasize the importance of exploiting peripheral resources and competencies to renew the firm's core competencies through building and developing complementary competencies. They suggest that in the more successful companies, strategic change appears to involve the ability to sustain value creation and innovation through revitalizing core competencies and creating new complementary competencies (Dyer and Singh 1998). The main theme in these studies is that evolutionary innovation arising from traditional routines and from the refinement of core competencies, along with the acquisition of complementary resources and competencies, are key elements in corporate strategies of firms in the fast-changing industry sector of high-growth, high-tech industries. Reordering peripheral competencies into core competencies reduces inertia and the risk implied by change (Ruiz-Navarro 1998).

The acquisition strategy of Cisco Systems Inc. is a good example of a technology-intensive company looking for smaller acquisition targets that excel in specific areas where Cisco wants to build its competencies. Cisco's run of 25 acquisitions between 1993 and 1998 transformed a small Californian maker of high-tech switches and routing devices to a multi billion dollar market leader in network technologies.

The main theme of the resource-based view (RBV) is that firms attain competitive advantages from valuable and hard-to-replicate resources (Wernerfelt 1984). However, to sustain their advantages, firms need to change those resources as markets and technologies change. Teece, Pisano and Shuen (1997) address this issue by suggesting the importance of building 'dynamic capabilities', which require timely responsiveness and rapid and flexible product innovation, coupled with the management capability to effectively coordinate and redeploy internal and external competences. The redeployment of resources using mergers/acquisitions becomes an important issue particularly in M\&As where the primary motive is to acquire new technology that cannot be easily acquired through internal development. Because of the difficulty of acquiring these highly firm-specific and tacit resources in the market place, firms that want to acquire these firm-specific technological resources are likely to use mergers/acquisitions as their primary strategic option.

The main focus of this study concerns the impact of complementary resources on $\mathrm{M} \& \mathrm{~A}$ performance. We suggest that the acquisition of a target firm's resources that complement an acquiring firm's other resources - i.e., direct complementarity - should be a key factor in today's M\&As. The technology-intensive sector is a good place to test this hypothesis mainly because of its dynamic and uncertain nature. Due to the speed of changes in technology and market conditions as well as the ever-increasing technological complexity and path-dependent characteristics in developing core competencies, internal development of unique resources often 
fails to create resources/capabilities that can be the basis of sustained competitive advantages for older firms in technology-intensive industries. Even if these firms were able to develop them, it might not be fast enough given the fast-changing technological and market conditions.

As Mitchell (1994) points out in his study of business divestiture by start up furms and diversifying entrants, the most common case of M\&As in the technology intensive sector occurs when a buyer acquires a small business that has not been able to attain large-scale commercial success but possesses valuable technological resources/capabilities. Many of these types of small businesses are not viable independently but offer technological resources that may be valuable to acquirers who have complementary resources.

\section{HYPOTHESES}

In a recent study of resource redeployment following horizontal acquisitions, Capron, et al. (1998) found that acquiring firms are more likely to redeploy financial resources to targets than from targets. The study suggests that acquiring a firm can serve as a means by which an acquiring firm employs excess financial resources to provide financial resources to support the growth of target businesses, which sometimes find it difficult or costly to raise capital (Chatterjee 1986).

The problem of very high external financing costs can also be applied to small and young firms - particularly to firms in the technology-intensive sector. The information asymmetry between these firms and external capital markets comes primarily from the relatively low level of public information and investor analysis and/or the highly uncertain and complex technology of these firms. The fact that target firms are, on average, considerably smaller in size than acquiring firms in high-tech mergers/acquisitions also contributes to the borrowing constraints since small-sized firms are found to suffer more from information asymmetry (Martinelli 1997). Hence,

\section{Hypothesis 1: The level of complementarities between technological and financial resources is positively related to firm performance.}

Most of the prior research in investigating technological and marketing resources argues that they operate independently with regard to their effect on new product or technology outcomes (Song and Parry 1997). Recently, however, Moorman and Slotegraaf (1999) found that marketing and technological resources/capabilities jointly influence the degree to which firms improved the quality of their brands and the speed of these quality improvements. Marketing capability refers to a firm's ability to develop and maintain relationships with customers including both end users and marketing channel members. A firm's customer and marketing orientation, 
defined as the ability to use market intelligence about exogenous market factors that influence current and future customer needs, has proven to be related positively to business performance (Deshpande, Farley and Webster 1993). In addition to these effects, marketing capability may create barriers to entry (Reve 1986) and has been found to provide a competitive advantage when managed effectively (Heide 1994), especially in conditions of high environmental uncertainty (Noordewier, John and Nevin 1990).

We suggest that new product and technology development is most effective when firms exhibit both marketing and technological capability. When both resources are properly utilized, new product and technology development can benefit from their complementarities (Milgrom and Roberts 1995). Marketing resources can improve the effect of the technology resources. Dierickx and Cool (1989) point out that because new product and process development find their origin in customer requests or suggestions, it may be harder for firms who do not have an extensive service network to develop technological know-how. This complementarity is also evident in Teece's (1987) examples of successful commercializations of new drugs as being dependent on the presence of specialized sales support. In light of this evidence, it is hypothesized that the performance of an M\&A will be positively influenced by the level of complementarities between technological and marketing resources. Hence,

\section{Hypothesis 2: The level of complementarities between technological and marketing resources is positively related to firm performance.}

The presence of strong operational resources in manufacturing companies entails the integration and coordination of a complex set of tasks - combining components and materials from different sources and industries - while enabling the firm to offer its final products at a competitive cost (Hayes, Wheelright and Clark 1988). The great complexity of the operations function helps to make superior operational resources imperfectly mobile and imperfectly imitable, thereby giving competitive advantage to firms that possess them. Sometimes the competition is based not on better product design or quality, greater marketing ingenuity, or superior financial strength, but on the ability to make products and operation processes more efficient, reliable, and precise.

High levels of financial and/or marketing resources of a firm do not always guarantee strong operational skills. In an environment characterized by insufficient resources, fierce competition, high customer expectations, and fast rates of change, firms are turning to supply chain management and time-based initiatives to strengthen distribution channel integration and thereby provide sustainable competitive advantage (Claycomb, Droge and Germain 1999).

Operational capability for a technology-intensive firm becomes more critical as the level of uncertainty and complexity of product and technology increases. Beckman 
(1990) emphasizes the importance of both process and product dimensions in a modern manufacturing firm claiming that a technology-intensive firm should be able to cope with five types of variability - demand, supply, product, process, workforce and equipment.

The way in which $R \& D$, representing a firm's technological resources, can make a contribution to the overall flexibility of the organization is through the application of a set of standard design rules and the use of a standard set of components in the product designs (Beckman et al. 1990). Both technological and operational resources are critically important to the ability of the entire organization to produce and deliver new products to the market place in a timely fashion. For example, it has become quite common to embed a set of design rules in the computer-aided design packages used by product engineers. These rules direct the designer to use product characteristics that best match the production process currently in place.

Based on the preceding arguments, complementarities between operational resources and technological resources can be one of the factors that determine the outcome of the mergers/acquisitions. Hence,

Hypothesis 3: The level of complementarities between technological and operational resources is positively related with firm performance.

\section{METHODS}

\section{Data \& Sample}

This study analyzed all completed M\&A deals in technology related industries over the 1984-1996 period. The data was obtained from the Securities Data Company (SDC)'s Worldwide Mergers and Acquisitions Data Base. Although SDC reports on some M\&As prior to 1984 , it lacks a comprehensive set of the M\&A activity for the periods prior to 1984 . We thus limited our attention to the post-1984 period. This study looked only at publicly traded firms because we used two dependent variables, one of which was a measure of ex ante performance. This required that a stock price be available for both the time of the M\&A announcement and for calculating the returns the participating firms earned in prior periods. The sample period ends at the end of 1996 because up to five years of long-term operating performance data (1997-2001) was required for our second performance-related dependent variable. In the case of mergers, we considered the acquiring firm to be the larger firm in terms of total market capitalization in this study. Sample analysis shows that on average, acquiring firms of the M\&As in the technology intensive sector are about ten times bigger than the target firms. Table 1 describes the SDC database on mergers and acquisitions. 


\section{Table 1. Securities Data Corporation's (SDC) 'Worldwide MERgERS/ACQUisitions' DATABASE}

\begin{tabular}{c|l}
\hline Data range & 1979-present for U.S. firms \\
\hline Data source & Over 200 news sources, SEC filings, trade publications, etc. \\
\hline Transactions & $\begin{array}{l}\text { All corporate transactions involving at least } 5 \% \text { of the ownership } \\
\text { of a company. }\end{array}$ \\
\hline
\end{tabular}

The total number of completed $M \& A s$ where the target firm belonged to the technology-intensive sector between 1984-1996 was 889. However, only 259 or these deals had all the required data for both acquiring and target firms. More than 50 percent of the M\&As in the sample were from the 1994-996 period, which shows the accelerating pace of M\&A activity in the mid 1990s. Table 2 summarizes sample statistics for this study.

TABle 2. SAMPle STATISTICS

\begin{tabular}{|c|c|c|c|}
\hline & \multicolumn{3}{|c|}{ M/A SAMPLE } \\
\hline Sample Industry & \multicolumn{3}{|c|}{ Technology-Intensive (for acquired firms) } \\
\hline Sample Period & \multicolumn{3}{|c|}{ 1984-1996 } \\
\hline $\begin{array}{l}\text { Number of Deals in the Sample } \\
\text { Sub-Periods* }\end{array}$ & \multicolumn{3}{|c|}{$\begin{array}{l}\text { 1984-1996: } 254 \text { (sample total) } \\
\text { 1984-1989: } 75 \\
\text { 1990-1996: } 179 \\
\text { 1990-1993: } 49 \\
\text { 1994-1996: } 130\end{array}$} \\
\hline \multirow{4}{*}{ Sample Description } & & Acquirer & Acquired \\
\hline & Avg. Size & 4.93 bil. & 0.46 bil. \\
\hline & Largest & 75.6 bil. & 22.7 bil. \\
\hline & Smallest & 0.04 bil. & 0.001 bil. \\
\hline
\end{tabular}

NOTE: * The number of deals here represents the number of M/A deals in the technology-intensive sector that had all the required data for both acquiring and acquired firms

Table 3 shows the distribution of M\&A activity in our sample across 5 of the industries drawn from the SDC database. As can be seen, over $80 \%$ of the firms involved in high technology $M \& A$ transactions included in this study came from the following industries: the biotechnology industry (which led with about 25\% of all acquirers and $18.5 \%$ of all targets), computer equipment and computer software and services (combined, the computer-related industries accounted for over $35 \%$ of both acquirers and targets in our sample), electronics and communications. 


\section{TABle 3. Key INDUSTRIES REPRESENTED IN SAMPLE AND DISTRIBUTION OF ACQUIRERS AND TARGETS}

\begin{tabular}{l|c|c}
\hline \multirow{2}{*}{ Industry Category } & \multicolumn{2}{|c}{ Number of firms } \\
\cline { 2 - 3 } & Acquirers & Targets \\
\hline Biotechnology & $64(24.7 \%)$ & $48(18.5 \%)$ \\
Computer Equipment & $54(20.8 \%)$ & $59(22.8 \%)$ \\
Computer Software \& Services & $39(15.1 \%)$ & $43(16.6 \%)$ \\
Electronics & $34(13.1 \%)$ & $41(15.8 \%)$ \\
Communications & $22(8.5 \%)$ & $22(8.5 \%)$ \\
Others & $46(17.8 \%)$ & $46(17.8 \%)$ \\
Total & $259 *(100 \%)$ & $259(100 \%)$ \\
\hline
\end{tabular}

NOTE: * There were 32 acquirers who made more than one acquisition during the sample period

\section{Dependent Variables}

To measure the performance of M\&As in technology-intensive industries, this study used two measures. We felt two measures are needed to capture both the immediate (short-term) reaction to the impending merger or acquisition and the longer-term effects of post-merger integration. Our first (short-term) measure was the stock market return adjusted for risk at the time of the merger/acquisition announcement. Our longer-term measure was the change in sales growth of the firm following the merger or acquisition.

\section{(1) Abnormal Stock Returns}

Abnormal returns can represent an ex ante measure of performance because, depending on the time period over which they are calculated, they can capture the expected financial returns associated with future firm performance (Anand and Singh 1997). In our case, we used the time period immediately following the announcement of a merger or acquisition. Returns were computed assuming that daily common stock returns are described by the market model employed by Loderer and Mauer (1992), which has been used by many other event studies (Chatterjee and Lubatkin 1990; Singh and Montgomery 1987).

The market model methodology used in this study has the following five steps: 1) determine the exact date of the first public announcement of each M\&A;2) define the estimation period and event period for the study; 3) gather the relevant price and dividend data for this period (this data came from the Center for Research in Securities Prices (CRSP) files); 4) calculate the abnormal returns for both acquiring and target firms (we used the market and risk adjusted model); and 5) add the abnormal returns of acquiring and target firms for the event period. The abnormal stock returns can be represented by the following formula: 


$$
A R_{i t}=R_{i t}-\left(\alpha_{i}+\beta_{i} R_{m t}\right)
$$

$A R_{i t}$ is the abnormal return on stock $\mathrm{i}$ for day $\mathrm{t} ; R_{i t}$ is the observed return on stock $\mathrm{i}$ for day t; $R_{m t}$ is the return on the market portfolio for day $\mathrm{t} ; \alpha_{i}$ is a constant and $\beta_{i}$ is the beta of stock $\mathrm{i}$ (which is a measure of nondiversifiable risk).

This method assumes that $\alpha$ and $\beta$ are stable and are calculated over an estimation period prior to the event in question. The estimation period used in this study is 230 days, from 250 days to 21 days before the event. To determine the short-term influence of a merger/acquisition event on a firm, abnormal returns are averaged over an event window surrounding the acquisition announcement. For this study we used the period between the day before announcement and the announcement day (i.e., $[-1,0]$ ).

\section{(2) Sales Growth}

We measured the longer term performance of the post-M\&A firm by calculating the change in average sales revenue growth of the post-acquisition firm from that of the combined acquiring and target firms. Since strategic growth is often mentioned by top managers of acquiring firms as a primary motivation for the acquisition (Biggadike 1979; Mitchell 1994; Yip 1982), we felt this represented an appropriate way to capture longer-term effects. Data was obtained from the COMPUSTAT database. The change in sales growth was calculated for a period of five years prior to and following the acquisition, which is consistent with prior studies (e.g., Healy, Palepu and Ruback 1993). To determine if the choice of period made a difference, we also ran our models using three and four-year windows (prior to and after merger date). All results for these analyses were consistent with those reported in this paper.

\section{Independent Variables}

Data for our resource-related independent variables were obtained from Standard \& Poor's COMPUSTAT database.

\section{(1) Technological Resources}

We used $R \& D$ intensity to measure the level of technological resources possessed by a firm. It was calculated as the annual dollar amount of research and development expense as a percentage of sales revenue. $\mathrm{R} \& \mathrm{D}$ expenditures relate to a firm's endowment of current and potential knowledge possessed by individuals and teams within the organization (Caves 1982; Macdonald 1985). R\&D intensity has been widely used in the strategy literature as a proxy for such intangible resources as innovative skills and activity (Chatterjee and Wernerfelt 1991), and technological 
resources (Mauri and Michaels 1998; Schoenecker and Cooper 1998). While other measures have been used such as patents (DeCarolis and Deeds 1999), the fact that we sampled across a wide range of industries meant that we might have included industries where patents were less important or less frequently sought by the firms in these industries. Since others have indicated that $R \& D$ expenditures can represent a firm's endowment of current and potential knowledge possessed by individuals and teams within the organization (Caves 1982; Macdonald 1985), we felt this measure represented a more appropriate measure in light of our sample of firms.

To eliminate any extraordinary occurrences in a particular year, this study used a three year average $R \& D$ intensity measure, the three years prior to but not including the M\&A announcement year - for both target and acquiring firms.

\section{(2) Financial Resources}

The level of financial resources available to the firm come from essentially two sources: available investment balances that can be used for capital expenditures (e.g., cash on hand), and incremental debt capacity that can be supported from anticipated cash flows (excluding interest earnings on available investment balances). Consequently, we employed a combination of these measures representing these two types of financial resources. We calculated the firm's current ratio, a standard measure for liquidity, by dividing current assets by current liabilities. We also calculated the firm's equity/debt (E/D) to represent incremental debt capacity (Chatterjee and Wernerfelt 1991; Palepu 1986). We calculated each over the three year period prior to (but not including) the year of the merger/acquisition for both target and acquirer and then averaged these two measures together for each firm.

\section{(3) Marketing Resources}

This study used marketing (advertising) intensity as a proxy for a firm's marketing resources. Marketing expenditures capture a firm's intangible assets such as brand name and reputation (Dutta, Narashimah and Rajiv 1999). Mahoney and Pandian (1992) also suggest that advertising intensity is a reasonably effective proxy for capturing these intangible assets. The expenditures over the years on marketing activities such as distribution and trade promotion efforts to build trade loyalty has been suggested in the marketing literature as one of the main resources that help achieve better targeting and positioning of a firm's brands relative to competing brands which enable the firm to enjoy higher margins and hence exhibit better financial performance (Day 1994; Jaworski and Kohli 1993). Several studies have documented a positive relationship between advertising investments and diversification (Hill and Hansen 1991) and advertising investments and market share (Assmus, Farley and Lehman 1984; Tellis 1988). 
We employed a three-year average (the three years prior to, but excluding the year of the merger/acquisition) of advertising expenditures, standardized by the corresponding total sales revenue of the firm for both target and acquiring firms.

\section{(4) Operational Resources}

We employed two measures of operational resources: the average inventory turnover and an efficiency-based measure of the average ratio of cost of goods sold (COGS) to total revenue. These two averages were, in turn, averaged together to arrive at our final measure of operational resources. We used the inverse of ratio of COGS to total revenue in this average so that for both components, larger numbers would represent greater levels of operational resources. Proper inventory management has long been suggested as a major factor for successful operations management (Gilbert and Ballou 1999; Singhal and Raturi 1990). Inventory includes all those goods and materials that are used in the production and distribution processes. Raw materials, component parts, subassemblies, and finished products are all part of inventory, as are the various supplies required in production and distribution processes (Fogarty, Hoffman and Stonebraker 1989). As Mather (1999) succinctly put it, high inventories are the result of a poor logistics flow. A three-year average (prior to, but not including the M\&A year) was calculated for inventory turnover. Inventory was measured by the sum of inventory levels (in dollars) of raw materials, work in process and finished goods at the end of the year and the start of the year, divided by two (e.g., [beginning inventory + ending inventory]/2). Inventory levels were divided into COGS to arrive at the inventory turnover for the year (COGS/Average Inventory).

Our second component measure of operational resources was a measure related to cost efficiency (De Meyer et al. 1989). It was calculated as the change in a firm's cost of goods sold divided by its total sales revenues. Since one of the key goals of operations in manufacturing firms is to produce at the lowest possible cost without compromising product quality, cost management becomes one of the business objectives of a firm's operations/manufacturing function (Hayes et al. 1988). Although inventory level may be a good proxy in industries such as semiconductors and computer hardware, in which proper inventory management is a key to efficient production and process operations, it may not correctly reflect the operational resources of such highly knowledge-based industries as computer software or biotechnology. Cost efficiency represents how efficiently a firm has been operating in terms of cost minimization. Our measure was again a three-year average prior to the $M \& A$, but excluding the year of the merger or acquisition.

\section{Control Variables}

Several control variables are included in the empirical model to account for other 
factors that could have an effect on our results. They are firm size, firm age, relatedness of mergers/acquisitions, method of payment, and prior M\&A experience. Data for firm size and age and relatedness were obtained from the COMPUSTAT database. Payment method and prior M\&A experience were determined with data drawn from the SDC database.

\section{(1) Firm Size}

We included a control for firm size because size has been found to impact product innovation and marketing efforts (Yeoh and Roth 1999; Ettlie and Rubenstein 1987; Capon, Lehman and James 1992). The scope of resource allocation such as money, people, and facilities are affected by firm size. We measured firm size by the log of total market capitalization of the acquiring and target firms at the time of the M\&A announcements. Other studies have used the $\log$ of total sales revenue as a proxy for size (Cool and Schendel 1987; Sharma 1998) but our measure has produced results consistent with those of these studies. The size of the combined post-acquisition firm ranged from $\$ 78.3$ billion to $\$ .04$ billion dollars with an average of $\$ 5.4$ billion.

\section{(2) Relatedness}

A solid stream of empirical studies has investigated whether corporate acquisitions with shared participation in similar product markets realize superior economic returns compared with unrelated acquisitions (Seth 1990b; Singh and Montgomery 1987). To allow for these possible effects, we employed a procedure used by Haleblian and Finkelstein (1999). We measured relatedness using 4-digit SIC codes from the six main lines of business (based on sales revenues) in which acquiring and target firms operated. Acquiring and target firms were classified as "related" if they had at least one 4-digit SIC code in common among the top six SIC codes in which they operated at the time of the acquisition. Otherwise, they were classified as "unrelated." Related M\&As were coded as 1, unrelated M\&As were coded as 0 . On average, the top six lines of business in our sample took up more than 80 percent of total sales revenue for acquirers, and almost 90 percent of total sales revenues for target firms. Just over $64 \%$ of the transactions were coded as related.

\section{(3) Method of Payment}

Studies published in the finance literature have found an association between the method of payment used for an acquisition and the acquirer's gains from the acquisition. (Asquith, Bruner and Mullins 1986; Travlos 1987). Asymmetric information and tax arguments are proposed as the major rationale behind choosing 
cash over stock, and vice versa, for payment of acquisition (Emery and Switzer 1999). A majority of these studies found that returns were negatively related to the proportion of equity in the offer, while others have shown that when cash was the payment form, performance changes were greater than when stock was used (e.g., Linn and Switzer 2001). To allow for these possible effects, this study included a measure of whether any cash was included in the acquisition. This measure was coded ' 1 ' if any cash was used in a transaction and ' 0 ' if there was no cash involved. Cash was involved in 112 or $43.2 \%$ of all acquistions.

\section{(4) Firm Age}

Firm age was controlled, in part because prior studies have found that, among other things, it was correlated with innovation probability (Yin and Zuscovitch 1998), borrowing constraints (Martinelli 1997; Winker 1999), and firm growth (Evans 1987). Firm age is measured as the number of years the acquiring firm has been in existence since its incorporation. On average, acquiring firms were 19 years old, and ranged from 89 years to 2 years old.

\section{(5) Prior M\&A Experience}

Finally, several studies have shown that prior M\&A experience affects post-merger performance (Stylianou, Jeffries and Robbins 1996). We operationalized prior experience as a binary variable. A transaction that had the acquirer or target firm with prior $M \& A$ experience was coded ' 1 '; otherwise it was coded ' 0 '. Data for constructing this measure was obtained from the SDC database. Almost $53 \%$ of the deals in our sample were coded as having one or more partners with prior M\&A experience (137 out of 259).

\section{RESULTS}

The summary statistics and correlations for the variables in the study are shown in Table 4. Note that the average abnormal returns are negative for acquirers and positive (17.9 percent) for targets. Also note that the technology intensity for targets is substantially higher than for acquirers (19.5 percent versus 11.8 percent, respectively). The functional areas of marketing and finance, on the other hand, show considerably more intensity for acquirers than for targets. The only functional area where intensity is comparable is in the operations area. Most of the correlations are modest in magnitude, suggesting that multicolinearity is not a problem. The highest statistically significant correlation is for combined firm size and prior M\&A experience $(.44, \mathrm{p}<.05)$ - not a surprising result. 
Table 4. Descriptive Statistics and Pearson Correlation Matrix ( $\mathbf{N}=259$ )

\begin{tabular}{|c|c|c|c|c|c|c|c|c|c|c|c|c|c|c|c|c|}
\hline Variables & Mean & S.D. & 1 & 2 & 3 & 4 & 5 & 6 & 7 & 8 & 9 & 10 & 11 & 12 & 13 & 14 \\
\hline 1. Abnormal Stock Returns & 0.17 & 0.26 & & & & & & & & & & & & & & \\
\hline 2. Changes in Sales Growth & 1.68 & 4.90 & $-0.14^{*}$ & & & & & & & & & & & & & \\
\hline $\begin{array}{l}\text { 3. Acquirer's technological } \\
\text { resources }\end{array}$ & 0.12 & 0.58 & 0.00 & 0.07 & & & & & & & & & & & & \\
\hline $\begin{array}{l}\text { 4. Target firm's technological } \\
\text { tesources }\end{array}$ & 0.19 & 2,48 & -0.09 & 0.00 & $0.20^{\text {*1*** }}$ & & & & & & & & & & & \\
\hline $\begin{array}{l}\text { 5. Acquirer's financial } \\
\text { resources }\end{array}$ & 6.45 & 11.88 & 0.02 & -0.37 & 0.04 & 0.04 & & & & & & & & & & \\
\hline $\begin{array}{l}\text { 6. Tatget firm's financial } \\
\text { tesoutces }\end{array}$ & 4.01 & 14.53 & -0.04 & 0.02 & -0.08 & -0.04 & -0.02 & & & & & & & & & \\
\hline $\begin{array}{l}\text { 7. Acquirer's marketing } \\
\text { resources }\end{array}$ & 0.04 & 0.19 & 0.02 & 0.03 & $0.13^{*}$ & 0.03 & 0.01 & $0.28 * *$ & & & & & & & & \\
\hline $\begin{array}{l}\text { 8. Target firm's marketing } \\
\text { resources }\end{array}$ & 0.02 & 0.02 & 0.06 & 0.06 & 0.04 & -0.01 & -0.09 & -0.03 & 0.05 & & & & & & & \\
\hline $\begin{array}{l}\text { 9. Acquirer's operational } \\
\text { resoutces }\end{array}$ & 6.14 & 9.67 & -0.05 & 0.01 & $-0.31^{*}$ & 0.08 & -0.04 & -0.07 & -0.05 & 0.09 & & & & & & \\
\hline $\begin{array}{l}\text { 10. Target firm's operational } \\
\text { resources }\end{array}$ & 6.20 & 20.67 & 0.43 & 0.01 & 0.06 & 0.06 & -0.06 & 0.07 & 0.01 & 0.02 & $0.15 *$ & & & & & \\
\hline 11. Combined firm size & 2.93 & 0.97 & $0.14 *$ & $-0.15^{*}$ & $-0.26 * *$ & -0.06 & -0.10 & 0.06 & -0.21 楼 & 0.07 & -0.08 & 0.10 & & & & \\
\hline $\begin{array}{l}\text { 12. Acquiret's prior M\&A } \\
\text { experience }\end{array}$ & 0.54 & 0.52 & $0.18^{\text {s** }}$ & -0.08 & $-0.19^{* * *}$ & -0.08 & 0.00 & $0.14^{*}$ & $0.23 * *$ & 0.02 & $-0.15 \%$ & 0.02 & $0.44 * *$ & & & \\
\hline 13. Method of payment & 0.44 & 0.50 & $0.17^{\text {*** }}$ & -0.10 & -0.07 & .0 .05 & 0.03 & -0.03 & -0.08 & 0.03 & $-0.16^{*}$ & 0.03 & 0.09 & 0.11 & & \\
\hline 14. Relatedness & 0.68 & 0.77 & 0.08 & -0.03 & 0.12 & 0.04 & $0.18^{* * *}$ & $-0.28^{* *}$ & 0.00 & 0.02 & 0.09 & -0.01 & $-0.14 *$ & -0.06 & 0.07 & \\
\hline 15. Firm age & 18.00 & 12.90 & 0.07 & -0.03 & 0.02 & 0.10 & -0.07 & -0.07 & -0.09 & $0.24 * *$ & 0.10 & 0.08 & 0.05 & $-0.16 *$ & 0.02 & -0.08 \\
\hline
\end{tabular}

NOTES: $* p<0.10 ; * * p<0.05$

\section{Short Term Performance}

The first set of results to be discussed below involves the effect of resource complementarity on short-term stock market performance. These results are presented in Table 5. Four models are shown. The first contains control variables and the main effects for the various resource categories for both targets and acquirers. Model 2 adds in the interaction effects for the target's technological resources and the acquirer's level of the other three resource categories (financial, marketing and operational resources). Model 3 adds the interaction effects for the acquirer's level of technological resources and the target's level of the other three categories. Model 4 contains both sets of interaction effects.

Hypothesis 1 predicted that complementarity between technological resources and financial resources would result in better firm performance. Table 5 shows strong support for this expectation when the dependent variable is abnormal returns at the time of the announcement of the merger/acquisition and technological resources are possessed by the target and financial resources by the acquirer. Models 2 and 4 have positive signs, indicating that higher levels of the components of the interaction (the target's technological resources and the acquirer's financial resources) result in higher abnormal returns, or, in other words a more favorable stock market reaction to the impending merger/acquisition $(\underline{b}=.0043$ (model 2 ) and $b=.0048$ 
(model 4) both $\mathrm{p}<.05$ ). Table 5 also reveals that when technological resources are possessed by the acquirer and financial resources are possessed by the target, there is no effect on abnormal returns $(\underline{b}=-.0089, p>.10$ (model 3) and $\underline{b}=-.0003$ (model 4), $\mathrm{p}>.10$ ).

Table 5. OlS Regression Results for EfFects of Complementary Resources DEPENDENT VARIABLE $=$ ABNORMAL STOCK RETURN AFTER ANNOUNCEMENT $(\mathbf{N}=259)$

\begin{tabular}{|c|c|c|c|c|}
\hline $\begin{array}{l}\text { Dependent variable: Abnormal stock } \\
\text { Returns at Announcement Date }\end{array}$ & Model 1 & Model 2 & Model 3 & Model 4 \\
\hline Constant & -0.0323 & -0.034 & -0.0283 & 0.0141 \\
\hline Acquirer's technological resources (ATR) & 0.0264 & 0.0281 & 0.0399 & $-0.2673 * *$ \\
\hline Target firm's technological resources (TTR) & -0.0085 & -0.0056 & -0.0096 & -0.0016 \\
\hline Acquirer's financial resources (AFR) & 0.0004 & 0.001 & 0.0003 & 0.0014 \\
\hline Target firm's financial resources (TFR) & -0.0006 & -0.0001 & 0.0008 & -0.0001 \\
\hline Acquirer's marketing resources (AMR) & 0.0428 & 0.06 & -0.0055 & -0.1105 \\
\hline Target firm's marketing resources (TMR) & 0.3392 & 0.5751 & 0.3838 & -0.7921 \\
\hline Acquirer's operational resources (AOR) & -0.0007 & -0.0014 & -0.0004 & -0.0013 \\
\hline Target firm's operational resources (TOR) & 0.0004 & 0.0002 & 0.0003 & 0.0002 \\
\hline Combined firm size & 0.0192 & 0.02885 & 0.0278 & 0.0263 \\
\hline Acquirer's prior M\&A experience & $0.0729 *$ & $0.0774 * *$ & $0.0693^{*}$ & $0.0803 * *$ \\
\hline Method of payment & $0.0730 * *$ & $0.0646 * *$ & $0.0662 * *$ & $0.0708 * *$ \\
\hline Relatedness & 0.0418 & -0.0119 & -0.0124 & -0.0027 \\
\hline Firm age & 0.0019 & 0.002 & 0.002 & 0.0018 \\
\hline $\mathrm{TTR} \times \mathrm{AFR}$ & & $0.0043 * *$ & & $0.0048 * *$ \\
\hline $\mathrm{TTR} \times \mathrm{AMR}$ & & $0.6002 *$ & & $0.6987 *$ \\
\hline $\mathrm{TTR} \times \mathrm{AOR}$ & & -0.0059 & & -0.0133 \\
\hline $\mathrm{ATR} \times \mathrm{TFR}$ & & & -0.0089 & -0.0003 \\
\hline ATR $\times$ TMR & & & $0.6212 * * * *$ & $9.2307 * * *$ \\
\hline ATR $\times$ TOR & & & -0.0001 & 0.0011 \\
\hline Model F & 1.95 & 1.81 & 2.1 & 2.02 \\
\hline p-value & 0.026 & 0.031 & 0.009 & 0.008 \\
\hline R-squared & 0.095 & 0.109 & 0.124 & 0.141 \\
\hline
\end{tabular}

NOTES: $* p<0.10 ; * * p<0.05 ; * * * p<0.01$

Hypothesis 2 predicted better performance when technological resources were combined with marketing resources. Table 5 again reveals that when technological resources are possessed by the target and marketing resources are possessed by the acquirer, stock market reaction is more favorable. That is, although the significance is only marginal, the abnormal returns are higher $(\mathrm{b}=.6, \mathrm{p}<.10($ model 2$) ; \mathrm{b}=.7$, 
$\mathrm{p}<.10$ (model 4)). In addition, models 3 and 4 of Table 5 show that when the acquirer possesses technological resources and the target marketing resources, there is also a positive effect on stock market reaction to the announcement of the merger/acquisition $(\underline{b}=.6, p<.01$ (model 2); $\underline{b}=9.2, p<.01$ (model 4)). These results provide some strong support for hypothesis 2 .

Hypothesis 3 focused on the complementarity between technological and operations resources and predicted that such complementarity would lead to better firm performance. When performance is measured by abnormal stock market returns, Table 5 reveals no support for this contention. All interaction effects for technological and operational resources are not significant, regardless of which party brings what to the table. Hypothesis 3 is thus not supported.

\section{Longer term performance}

We also tested our hypotheses using a dependent variable that represented longer-term performance. This variable was the change in sales growth from a five-year period prior to the merger/acquisition to the five-year period immediately following the completion of the merger/acquisition. The results for these analyses appear in Table 6. The four models shown are analogous to those in Table 5 in that the first only contains main effects and control variables. Model 2 adds the interactions between the target's level of technological resources and the acquirer's level of financial, marketing and operational resources, respectively. Model 3 adds the interaction between the acquirer's technological resources and the target's levels of financial, marketing and operational resources to Model 1 of Table 6. Model 4 contain all interactions between the target's level of resources and the acquirer's.

As previously stated, our hypothesis looked at the complementarity between technological and financial resources and marketing and operational resources, and their effect on performance. Using change in sales growth as the dependent variable, Models 2 and 4 of Table 6 show that when the target brings technological resources to the merger/acquisition and the acquirer brings financial, marketing or operational resources to the combined firm, there is a significant effect on subsequent sales growth. When the acquirer brings financial (hypothesis 1) or marketing (hypothesis 2) expertise to the table and the target brings technological expertise, sales growth increases following the merger/acquisition compared to the growth prior to the event (e.g., in Model 2: $\underline{b}=.46, p<.01$ for acquirer's financial resources; $\underline{b}=.50 .17$, $\mathrm{p}<.01$ for the acquirer's marketing resources). These results are quite consistent with hypothesis 1 and 2. However, the combination of the target's technological resources and the acquirer's operational resources result in decreased sales growth following the merger/acquisition. That is, performance declined when a target's technological expertise was combined with an acquirer's operational skills. This is directly counter to hypothesis 3 and we will return to this result in the discussion.

When the acquirer's technological skills were combined with a target's financial 
resources, (Models 3 and 4), the effect on sales growth was positive (in Model 3 , e.g., $\underline{b}=.876, \mathrm{p}<.01$ ), supporting hypothesis 1 . However, when an acquirer brought technological resources and the target brought more marketing resources, the effect on subsequent sales growth was negative (e.g., in Model 3: $\underline{b}=-15.3$, $\mathrm{p}<.01$ ), contrary to hypothesis 2 . The effect of the combination of an acquirer's technological resources and the target's operational resources had no significant effect on subsequent sales growth (in Models 3 and 4 both coefficients were $\mathrm{p}>.10$ ).

Table 6. Ols Regression Results for EFFeCts of Complementary Resources DEPENDENT VARIABle = FIVE-Year CHANGE IN SALES GrowTH $(\mathbf{N}=259)$

\begin{tabular}{|c|c|c|c|c|}
\hline $\begin{array}{c}\text { Dependent variable: } \\
\text { Change in Sales Growth ( } 5 \text { years) }\end{array}$ & Model 1 & Model 2 & Model 3 & Model 4 \\
\hline Constant & $5.035 * * *$ & $5.1478 * * *$ & $5.0686 * * * *$ & $4.4772 * * *$ \\
\hline Acquirer's technological resources (ATR) & 0.462 & 0.256 & $-2.8704 * *$ & 1.5904 \\
\hline Target firm's technological resources (TTR) & -0.0358 & $-0.2854 *$ & -0.0464 & -0.1766 \\
\hline Acquirer's financial resources (AFR) & -0.0152 & $-0.0568 *$ & -0.0082 & $-0.056 * *$ \\
\hline Target firm's financial resources (TFR) & 0.006 & -0.0045 & $-0.0965 * * *$ & -0.0391 \\
\hline Acquirer's marketing resources (AMR) & -0.5839 & $-2.7801 *$ & 2.0395 & 0.086 \\
\hline Target firm's marketing resources (TMR) & 17.1017 & 3.6146 & 14.5195 & 16.975 \\
\hline Acquirer's operational resources (AOR) & -0.0225 & $0.0611 * *$ & -0.0281 & $0.0557 *$ \\
\hline Target firm's operational resources (TOR) & 0.0075 & 0.0159 & 0.0056 & 0.0042 \\
\hline Combined firm size & $-0.6956 *$ & $-0.9895 * * *$ & $-0.8862 * *$ & $-0.9406 * * *$ \\
\hline Acquirer's prior $M \& A$ experience & -0.1753 & -0.6432 & 0.063 & -0.5707 \\
\hline Method of payment & -0.8662 & -0.4694 & -0.5901 & -0.5157 \\
\hline Relatedness & -0.3646 & $1.0752 * *$ & 0.8056 & $0.9156^{*}$ \\
\hline Firm age & -0.0192 & -0.0249 & -0.0221 & -0.0255 \\
\hline TTR $\times$ AFR & & $0.4649 * * *$ & & $0.4976^{* * * *}$ \\
\hline TTR $\times$ AMR & & $50.1748 * * *$ & & $43.0745 * * *$ \\
\hline $\mathrm{TTR} \times \mathrm{AOR}$ & & $-0.3537 * * * *$ & & $-0.3466 * * *$ \\
\hline $\mathrm{ATR} \times \mathrm{TFR}$ & & & $0.8762 * * *$ & $0.3321 * *$ \\
\hline ATR $\times$ TMR & & & $-15.323 * * *$ & $-95.3595 *$ \\
\hline ATR $\times$ TOR & & & 0.041 & 0.1077 \\
\hline Model F & 0.84 & 11.32 & 2.9 & 10.23 \\
\hline p-value & 0.617 & $<0.0001$ & 0.0002 & $<0.0001$ \\
\hline R-squared & 0.043 & 0.4332 & 0.163 & 0.454 \\
\hline
\end{tabular}

NOTES: * $\mathrm{p}<0.10 ; * * \mathrm{p}<0.05 ; * * * \mathrm{p}<0.01$

As we noted previously, we also tested the Models in Table 6 using threeand four-year changes in sales growth as the dependent variable. Results using 
these dependent measures were substantially the same as those reported here. The explanatory power of the various models was also reasonably strong. R-squared figures ranged from 18\% (Model 3 of Table 5) to $45 \%$ (Model 4 of Table 6), indicating that variables included were strongly predictive of future performance. The models of Table 4 report much higher r-squared figures that those in Table 5, suggesting that resource complementarity plays a stronger role in operational results (such as sales) than in stock market reactions. In particular, r-squared jumps from .04 to .43 as the three interaction terms are added to Model 1 in Table 6 to yield Model 2. This is a much bigger increase than when the interaction terms representing the acquirer's technological resources and the target's financial, marketing and operational resources are added to Model 1 to yield Model 3. R-squared increases to only 0.16 in this case, but almost triples when the interactions representing the target's technological resources and the acquirer's other resources are added to Model 3 to yield Model 4 of Table 6 .

\section{Control variables}

The results in Table 5 show that virtually none of the main effects were significantly related to the abnormal stock returns following announcement. Of the control variables, having more experience with M\&As and including some cash in the payment for the target resulted in higher abnormal returns. Model 4 shows some evidence of the main effects, but no consistent results across the four models. Firm size, however was negatively related to sales growth change in all four of the models in Table 6 (all $\mathrm{p}<.01$ ). In addition, the relatedness of the merger/acquisition was positively related to change in sales growth for the complete model, although the relationship was only marginally significant $(\underline{b}=.92, p<.10)$. The relationship was also positive for Model 2, which contained interactions of the target's technological resources and the acquirer's financial, marketing and operational resources $(b=1.08$, $\mathrm{p}<.05$ ). Table 7 summarizes the test results of this study.

TABle 7. Summary of Results

\begin{tabular}{|c|c|c|c|c|}
\hline Hypothesis & $\begin{array}{c}\text { Interaction } \\
\text { variables } \\
\text { (complementarity) }\end{array}$ & $\begin{array}{l}\text { Expected } \\
\text { relationship } \\
(\text { sign })\end{array}$ & $\begin{array}{c}\text { Effects on } \\
\text { announcement } \\
\text { returns }\end{array}$ & $\begin{array}{l}\text { Effects on } \\
\text { changes in } \\
\text { sales growth }\end{array}$ \\
\hline \multirow{2}{*}{$\mathrm{H} 1$} & TTR $\times$ AFR & + & $+* *$ & $+* * *$ \\
\hline & ATR $\times$ TFR & + & & $+* *$ \\
\hline \multirow{2}{*}{$\mathrm{H} 2$} & TTR $\times$ AMR & + & $+* *$ & $+* * *$ \\
\hline & $\mathrm{ATR} \times \mathrm{TMR}$ & + & $+* * *$ & $-* *$ \\
\hline \multirow{2}{*}{$\mathrm{H} 3$} & TTR $\times$ AOR & + & & $* * *$ \\
\hline & ATR $\times$ TOR & + & & + \\
\hline
\end{tabular}




\section{DISCUSSION}

This paper set out to investigate the impact that direct resource complementarity has on the performance of the post-merger/acquisition firm. We hypothesized that, in situations typical of merger and acquisition activity in technology-intensive industries, when an acquiring firm acquires technological capabilities from its target while contributing its own expertise in other areas of the firm (financial, marketing and/or operational), better post-merger performance will result. This prediction was confirmed for both marketing and financial resources for both short and longer-term dependent measures. In addition, our results also suggest that this is not the only resource combination that can lead to better post-acquisition outcomes. When the acquiring firm contributed technological resources and the target possessed financial resources, better longer-term performance resulted (measured by changes in sales growth). Similarly, the combination of acquirer's technological resources and the target's marketing resources led to better short-term stock market reaction to the merger/acquisition announcement.

Unexpectedly, we found that when an acquirer possesses superior operational resources and attempts to combine them with technological resources supplied by the target, longer term performance appears to suffer. This was contrary to our expectation in hypothesis 3. The result may stem from the inherent inconsistency between these two resource bases, particularly in industries where technology is changing rapidly. In these cases, operational resources are likely to be dedicated to efficiency-related goals and benefit from their stable, well-developed nature. When newer technologies emerge, however, they may disrupt the dominance of such tried-and-true technology. In these cases, the newer technology is not compatible with the operational expertise possessed by the acquirer, and attempts to integrate this disruptive technology into existing manufacturing capabilities instead produces poorer outcomes. This reasoning is consistent with the idea that competence-destroying technological discontinuities typically emerge from newer firms, just the type that might be acquired in $\mathrm{M} \& \mathrm{~A}$ activity in technology intensive industries (Tushman and Anderson 1986).

This result suggests that managers of firms that possess significant operational capabilities need to exercise additional care when contemplating acquisition of new technology through M\&A activity. While our 5-year window suggests that the problems that stem from trying to wed new technology with established operational expertise are not short-term phenomena, it is unclear how long the process would take to succeed, if indeed it ever does. This represents an important area for future researchers to examine. With additional study, the conditions that facilitate these types of combinations can be identified more readily.

One possible area for examination is the negative correlation between a high-tech firm's focus on profitability by emphasizing superior operating efficiency and a firm's innovation capacity. In other words, an acquiring firm which focuses on 
cost efficiency may not be strong in managing an entrepreneurial environment where developing new product/technology and gaining market share as quickly as possible are the highest priorities. Consequently, if such a firm has had a history of strong intrepreneurship through its internal development of new technologies, it may be in a better position to absorb these types of technologies when they come from acquired firms than a firm without such prior experience.

In summary, a firm's financial and marketing resources coupled with the merger partner firm's technological resources had a significant positive impact on merger performance. The impact of resource complementarities between acquiring and target firms were particularly significant when the merger was between an acquiring firm with strong financial and marketing resources and a target firm with strong technological resources.

Finally, the results of this study have significant implications for the theory and practice of mergers/acquisitions. They indicate that a focus on specific, complementary resources rather than on product or market relatedness is important for M\&A performance. Our results may provide an explanation for the inconsistent results in existing research on the performance differences between related vs. unrelated M\&As. When evaluating potential target firms, corporate managers who pursue an acquisitive growth strategy may benefit more by concentrating on the complementarities in resource flows between acquiring and target firms rather than on the similarities in products or strategy types.

\section{REFERENCES}

Anand, J. and Singh H. 1997. Asset redeployment, acquisitions and corporate strategy in declining industries. Strategic Management Journal, Summer Special Issue, 18: 99-118.

Asquith, P., Bruner, R. F. and Mullins, D. W. 1986. The Gains to Bidding Firms from Merger. Journal of Financial Economics 11(1-4): 121-139.

Assmus, G., Farley J. U., and Lehman D. R. 1984. How advertising affects sales: Meta-analysis of econometric results. Journal of Marketing Research 21(February): 65-74.

Barney, J. B. 1988. Returns to bidding firms in mergers and acquisitions: Reconsidering the relatedness hypothesis. Strategic Management Journal 9(Summer): 71-78.

Barney, J. B. 1991. Firm resources and the theory of competitive advantage. Joumal of Management 17: 99-120.

Beckman, S. L. 1990. Manufacturing Flexibility: The Next Source of Competitive Advantage. Strategic Manufacturing: Dynamic New Directions for the 1990s, (P.E. Moody, editor), Homewood IL: Dow-Jones Irwin: 107-132.

Biggadike, R. 1979. The risky business of diversification. Harvard Business Review 57(3): 103 . 
Blonigen, B. A. and Taylor C. T. 2000. R\&D intensity and acquisitions in high-technology industries: Evidence from the US electronic and electrical equipment industries. Journal of Industrial Economics 48(1): 47-70.

Brush, T.H. 1996. Predicted change in operational synergy and post-acquisition performance of acquired businesses. Strategic Management Journal 17(1): 1-24.

Capron, L., Dussauge, P. and Mitchell, W. 1998. Resource redeployment following horizontal acquisitions in Europe and North America, 1988-1992. Strategic Management Journal 19(7): 631-661.

Capon, N. F., Lehmann, J. U., Donald R. H., and James, M. 1992. Profiles of product innovators among large U.S. manufacturers. Management Science 38(2): 157-169.

Caves, R. E. 1982. Multinational Enterprise and Economic Analysis. Cambridge Surveys of Economic Literature, Cambridge, UK: Cambridge University Press.

Chatterjee, S. 1986. Types of synergy and economic value: The impact of acquisitions on merging and rival firms. Strategic Management Journal 7(2): 119-139.

Chatterjee, S. and Lubatkin, M. 1990. Corporate mergers, stockholder diversification, and changes in systematic risk. Strategic Management Journal 11(4): 255-268.

Chatterjee, S., Lubatkin M. H., Schweiger D. M., and Weber, Y. 1992. Cultural differences and shareholder value in related mergers: Linking equity and human capital. Strategic Management Journal 13(5): 319-334.

Chatterjee, S. and Wernerfelt, B. 1991. The link between resources and type of diversification: Theory and evidence. Strategic Management Journal 12(1): 33-48.

Claycomb, C., Droge, C., and Germain, R. 1999. The effect of just-in-time with customers on organizational design and performance. International Journal of Logistics Management 10(1): 37-58.

Cool, K.O. and Schendel, D. 1987. Strategic group formation and performance: The case of the U.S. pharmaceutical industry, 1963-1982. Management Science 33(9): 1102-1124.

Datta, D. K. 1991. Organizational fit and acquisition performance: Effects of post-acquisition integration. Strategic Management Joumal 12(4): 281-297.

Day, G. S. 1994. The capabilities of market driven organizations', Journal of Marketing 58(October): 37-52.

DeCarolis, D. M. and Deeds, D. 1999. The impact of stocks and flows of organizational knowledge on firm performance: An empirical investigation of the biotechnology industry. Strategic Management Journal 20(10): 953-968.

Deshpande, R., Farley, J. U., and Webster, F. E. 1993. Corporate culture, customer orientation, and innovativeness in Japanese firms: A quadrad Analysis', Journal of Marketing 52(January): 23-36.

Dierickx, I. and Cool, K. 1989. Asset stock accumulation and sustainability of competitive advantage. Management Science 33(12): 1504-1511.

Dutta, S., Narasimhan, O., and Rajiv S., 1999. Success in high-technology markets: Is marketing capability critical?. Marketing Science 18(4): 547-568. 
Dyer, J. H. and Singh, H. 1998. The relational view: Cooperative strategy and sources of interorganizational competitive advantage. Academy of Management Review 23(4): 660-679.

Eisenhardt, K. M. 1989. Making fast strategic decisions in high-velocity environments. Academy of Management Journal 32(3): 543-576.

Eisenhardt, K. M. and L. J. Bourgeois III, 1988. Politics of Strategic Decision Making in High-Velocity Environments. Academy of Management Journal 31(4): 737-770.

Emery, G. W. and Switzer J. A. 1999. Expected market reaction and the choice of method of payment of acquisitions. Financial Management 28(4): 73-86.

Ettlie, J. E. and Rubenstein, A. H. 1987. Firm size and product innovation. Journal of Product Innovation Management 4(2): 89-108.

Evans, D. S. 1987. Tests of alternative theories of firm growth. Journal of Political Economy 95(4): 657-674.

Fogarty, D. W., Hoffmann, T. R. and Stonebraker, T. W. 1989. Productions and Operations Management. Cincinnati OH: South-Western Publishing Co.

Gilbert, S. M. and Ballou, R. H. 1999. Supply chain benefits from advanced customer commitments. Journal of Operations Management 18(1): 61-73.

Haleblian, J. and Finkelstein, S. 1999. The influence of organizational acquisition experience on acquisition performance: A behavioral learning perspective. Administrative Science Quarterly 44(1): 29-56.

Harrison, J. S., Hitt, M. A., Hoskisson, R. E., and Ireland, R. D. 1991. Synergies and post-acquisitions performance: Differences versus similarities in resources allocations. Journal of Management 17(1): 173-190.

Hayward, M. L. A. and Hambrick, D. C. 1997. Explaining the premium paid for large acquisitions: Evidence of CEO hubris. Administrative Science Quarterly 42(1): 103-127.

Hayes, R. H., Wheelwright, S. C., and Clark, K. B. 1988. Dynamic Manufacturing: Creating the Learning Organization. London: The Free Press.

Healy, P. M., Palepu, K. G. and Ruback, R. S. 1993. Does corporate performance improve after mergers?. Journal of Financial Economics 31(2): 135-175.

Heide, J. 1994. Interorganizational governance in marketing channels. Journal of Marketing 58(January): 71-85.

Hill, C. W. L. and Hansen, G. S. 1991. A longitudinal study of the cause and consequences of changes in diversification in the U.S. Pharmaceutical industry 1977-1986. Strategic Management Journal 12(3): 187-199.

Jaworski, B. J. and Kohli, A. K. 1993. Market orientation: Antecedents and consequences. Journal of Marketing 57(July): 53-71.

Jemison, D. B. and Sitkin, S. B. 1986. Corporate acquisitions: A process perspective. Academy of Management Journal 11(1): 145-163.

Larsson, R. and Finkelstein, S. 1999. Integrating strategic, organizational, and human resource perspectives on mergers and acquisitions: A case survey of synergy 
realization. Organization Science 10(1): 1-26.

Linn, S. C. and Switzer J. A. 2001. Are cash acquisitions associated with better postcombination operating performance than stock acquisitions? Journal of Banking and Finance 25(6): 1113-1138.

Lippman, S. and Rumelt, R. 1982. Uncertain imitability: An analysis of interfirm differences in efficiency under competition. Bell Joumal of Economics 13(Autumn): 418-438.

Loderer, C. F. and Mauer, D. C. 1992. Corporate dividends and seasoned equity issues: An empirical investigation. Journal of Finance 47(1): 201-225.

Lubatkin, M. 1987. Merger strategies and stockholder value. Strategic Management Journal, 8(1): 39-53.

Macdonald, J. M. 1985. R\&D and the directions of diversification. The Review of Economics and Statistics 67(4): 583-590.

Mahoney, J. T. and Pandian J. R. 1992. The resource-based view within the conversation of strategic management. Strategic Management Journal 13(5): 363-380.

Marcus, A. and Geffen, D. 1998. The dialectics of competency acquisition: Pollution prevention in electric generation. Strategic Management Joumal 19(12): 1145-1158.

Markides, C. and Williamson, P. J. 1994. Related diversification, core competencies and corporate performance. Strategic Management Journal, (Special Issue - Summer): 149-166.

Martinelli, C. 1997. Small firms, borrowing constraints, and reputation. Journal of Economic Behavior E Organization, 33(1): 91-105.

Mather, H., 1999. Competitive Manufacturing, $2^{\text {nd }}$ Edition, Boca Raton, FL: CRC Press Co.

Mauri, A. J. and Michaels, M. P. 1998. Firm and industry effects within strategic management: An empirical examination. Strategic Management Journal 19(3): 211-219.

Milgrom, P. and Roberts, J. 1995. Complementarities and Fit: Strategy, Structure, and Organizational Change in Manufacturing. Journal of Accounting and Economics 19(2): 179-208.

Mitchell, W. 1994. The dynamics of evolving markets: The effects of business sales and age dissolutions and divestitures. Administrative Science Quarterly 39(4): 575-602.

Moorman, C. and Slotegraaf, R. J. 1999. The Contingency Value of Complementary Capabilities in Product Development. Journal of Marketing Research 36(May): 239-257.

Nelson, R. R. and Winter S. G. 1982. An Evolutionary Theory of Economic Cbange. Harvard University Press, Cambridge, MA.

Noordewier, T. G., John, G. and Nevin J. R., 1990. Performance outcomes of purchasing arrangements in industrial buyer-vendor relationships. Journal of Marketing 54(October): 80-93.

Palepu, K. G. 1986. Predicting takeover targets: A methodological and empirical 
analysis. Journal of Accounting and Economics 8(1): 3-35.

Peteraf, M. A. 1993. The connerstone of competitive advantage: A resource-based view. Strategic Management Journal 14(3): 179-192.

Reve, T. 1986. Organization for Distribution. In Research in Marketing, Vol. 8, P. Bucklin and J. M. Carmen, eds. Greenwich, CT: JAI Press: 1-26.

Ruiz-Navarro, J. 1998. Turnaround and renewal in a Spanish shipyard. Long Range Planning 31(1): 51-59.

Schoenecker, T. S. and Cooper A. C. 1998. The role of firm resources and organizational attributes in determining entry timing: A cross-industry study. Strategic Management Journal 19(12): 1127-1143.

Seth, A. 1990a. Value creation in acquisitions: A reexamination of performance issues. Strategic Management Journal 11(2): 99-105.

Seth, A. 1990b. Sources of value creation in acquisitions: An empirical investigation. Strategic Management Journal 11(6): 279-287.

Sharma, A. 1998. Mode of entry and ex post performance', Strategic Management Journal 19(9): 879-900.

Shelton, L. M. 1988. Strategic business fits and corporate acquisition: Empirical evidence. Strategic Management Journal 9(3): 279-287.

Singh, H. and Montgomery, C. 1987. Corporate acquisition strategies and economic performance. Strategic Management Journal 8(4): 377-386.

Singhal, V. R. and Raturi, A. S., 1990. The effect of inventory decisions and parameters on the opportunity cost of capital. Joumal of Operations Management 9(3): 406-420.

Sirower, M. 1997. The Synergy Trap: How Companies Lose the Acquisition Game. NY: Free Press.

Song, Z. M. and Parry M. E. 1997. The determinants of Japanese new product successes. Journal of Marketing Research 34(1): 64-76.

Stylianou, A. C., Jeffries, C. J. and Robbins, S. S. 1996. Corporate mergers and the problems of IS integration. Information Management 31(4): 203-213.

Teece, D. J. 1987. Technological change and the nature of the firm. In G. Dosi, C. Freeman, R. Nelson, G. Silverberg and L. Soete (eds.), Technical Change and Economic Theory, Pinter Publishers, New York.

Teece, D. J., Pisano, G. and Shuen, A. 1997. Dynamic capabilities and strategic management. Strategic Management Journal 18(7): 509-533.

Tellis, G. J. 1988. The price elasticity of selective demand: A meta-analysis of econometric models of sales. Journal of Marketing Research 25(November): 331-341.

Trautwein, F. 1990. Mergers motives and merger prescriptions. Strategic Management Journal 11(4): 283-295.

Travlos, N. G. 1987. Corporate takeover bids, methods of payment, and bidding firms' stock returns. Journal of Finance 42(4): 943-963.

Tushman, M. L. and Anderson, P. 1986. Technological discontinuities and organizational environments. Administrative Science Quarterly 31(3): 439-465. 
Walker, O. C. and Ruekert, R. W. 1987. Marketing's role in the implementation of business strategies. Journal of Marketing 51(July): 15-33.

Wernerfelt, B. 1984. A resource-based view of the firm. Strategic Management Journal 5(2): 171-180.

Winker, P. 1999. Causes and effects of financing constraints at the firm level. Small Business Economics 12(2): 169-181.

Yeoh, P. and Roth, K. 1999. An empirical analysis of sustained advantage in the U.S. pharmaceutical industry: Impact of firm resources and capabilities. Strategic Management Journal 20(7): 637-653.

Yin, X. and Zuscovitch, E. 1998. Is firm size conducive to R\&D choice? A strategic analysis of product and process innovations. Journal of Economic Bebavior $\mathcal{E}$ Organization 35(2): 243-262.

Yip, G. S. 1982. Diversification entry: Internal development vs. acquisition. Strategic Management Journal 3(4): 331-345. 